\title{
SISTEM PENAPISAN DERAU PADA SENSOR INERSIA WAHANA TANPA AWAK QUADROTOR
}

\author{
Meilia Safitri \\ Program Vokasi, Program Studi Teknik Elektromedik \\ Universitas Muhammadiyah Yogyakarta \\ Email: meilia.safitri@vokasi.umy.ac.id \\ Nur Hudha Wijaya \\ Program Vokasi, Program Studi Teknik Elektromedik \\ Universitas Muhammadiyah Yogyakarta \\ Email: nurhudhawijaya@umy.ac.id
}

\begin{abstract}
ABSTRAK
Dalam penelitian ini dirancang algoritme penapisan yang bertujuan untuk mengurangi derau yang ada pada hasil pengukuran sensor inersia quadrotor. Kalman filter digunakan untuk menapis derau yang tercampur pada data hasil pengukuran sensor accelerometer dan gyroscope. Selain itu, algoritme zero velocity compensator dirancang untuk menghilangkan pergeseran ketika quadrotor berada dalam keadaan statis. Berdasarkan pengujian yang telah dilakukan algoritme zero velocity compensator yang dirancang telah mampu mengurangi pergeseran (drift) pada saat quadrotor dalam keadaaan diam, selain itu Kalman filter yang digunakan pada sensor accelerometer dan sensor gyroscope telah dapat mengurangi derau yang tercampur pada raw data, sehingga hasil integrasi perpindahan lebih baik dibandingkan dengan hasil integrasi tanpa penapisan.
\end{abstract}

Kata kunci: kalman filter, zero velocity compensator, IMU.

\section{ABSTRACT}

In this study a filtering algorithm that aims to reduce existing noise on the measurement of the inertial sensors in quadrotor is designed. Kalman filter is used to filter the noise mixed in the measurement data of accelerometer and gyroscope censor. Meanwhile, to eliminate the drift that occurs when the quadrotor in static condition, the zero velocity compensator algorithm is employed. Based on the conducted experiment, the designed zero velocity compensator has been succesfully eliminate the drift when quadrotor in static condition. Moreover the proposed Kalman filter that is used in accelerometer and gyroscope censor has been able to reduce the noise mixed in raw data, with the result that the estimation of Kalman filter is better than the estimation without filtering.

Keywords: kalman filter, zero velocity compensator, IMU.

\section{PENDAHULUAN}

Wahana udara tanpa awak, unmanned aerial vehicle (UAV), merupakan wahana terbang tanpa ada yang mengendalikan penerbangan wahana tersebut. Sebuah UAV dapat berupa pesawat terbang yang dikendalikan dari jarak jauh atau pesawat yang terbang secara autonomous atau pesawat dengan sistem otomatis yang lebih dinamis dan kompleks. Salah satu jenis UAV yang banyak menarik perhatian peneliti dalam dekade terakhir ini adalah quadrotor. Quadrotor merupakan jenis UAV yang memanfaatkan empat buah rotor non-coaxial untuk bermanuver. Kemampuan-kemampuan quadrotor seperti hovering, piroutte, dan sideslip membuat jenis wahana udara tanpa awak ini semakin lihai dalam bermanuver selain itu, kemampuan quadrotor untuk melakukan vertical take off and landing (VTOL) membuat wahana ini tidak membutuh area yang besar untuk melakukan pendaratan dan lepas landas[1]. Saat ini pengembangan quadrotor menjadi semakin luas. Walaupun pengembangan quadrotor yang terbesar masih pada bidang militer akan tetapi pengembangan quadrotor dibidang kesehatan, perpetaan, pertanian juga semakin banyak.

Salah satu unsur penting pada quadrotor adalah kemampuan navigasi yang baik. Dalam merancang sebuah sistem navigasi pada quadrotor terdapat beberapa hal yang harus dihadapi [2] yaitu, beban (payload) yang terbatas, odometry tidak langsung, dan dinamika yang cepat. Keterbatasan beban yang dapat dibawa oleh sebuah quadrotor membuat pemilihan sensor yang dapat digunakan juga terbatas. Selain harus memiliki bentuk yang kecil dan ringan, pemilihan sensor juga harus memperhatikan konsumsi daya sensor. Disamping itu, dalam perancangan 
sistem navigasi juga harus mempertimbangkan aspek kompleksitas dalam proses komputasi. Proses komputasi yang berat membuat unit pemeroses harus melakukan perhitungan yang sangat banyak dalam waktu singkat sehingga membuat konsumsi daya meningkat. Dengan semua batas-batasan dan tantangan yang ada, perancangan sistem navigasi pada quadrotor semakin sulit sekaligus menantang untuk dilakukan. Apalagi dalam keadaan lingkungan yang tidak terjangkau oleh sinyal GPS semakin menambah tingkat kesulitan dalam merancang sebuah sistem navigasi dalam quadrotor. Dalam perancangan sistem navigasi quadrotor pada daerah yang tidak terjangkau oleh GPS, hanya dapat bergantung pada inertial measurement unit (IMU) dan sensor exteroceptive seperti laser range finder [3] [4] [5] dan kamera [6] [7] [8] [9].

Penggunaan laser range-finder dalam sistem navigasi quadrotor mempunyai kemampuan yang baik bila digunakan dalam lingkungan yang mempunyai struktur fisik atau yang unik, namun bila digunakan dalam lingkungan yang homogen misalnya didalam koridor suatu gedung hasil yang didapat tidak begitu akurat. Di lain pihak, penggunaan sensor kamera baik kamera biasa, stereo camera, maupun kamera RGB-D sangat baik bila digunakan untuk memperoleh informasi 3D, namun sensor ini mempunyai kelemahan pandangan secara angular dan membutuhkan komputasi yang intensif serta harga dari sensor ini cukup mahal.

Pada penelitian ini dikembangkan algoritma Kalman filter pada sistem navigasi yang berbasis sensor IMU. Sensor IMU memliki keunggulan yaitu harganya yang murah, ringan, dan memiliki komputasi yang ringan. Disamping itu penggunaan algoritma Kalman filter dalam penapisan noise sensor IMU membuat sistem navigasi yang dikembangkan memiliki komputasi yang ringan namun, tetap memiliki kemampuan yang baik dalam mengestimasi posisi UAV.

\section{MODEL SISTEM PARROT ARDRONE 2.0}

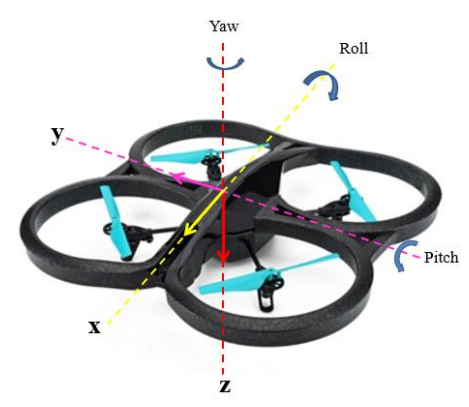

Gambar 1. Sistem Pergerakan Parrot ARDrone 2.0

Penelitian ini menggunakan quadrotor jenis Parrot ARDrone 2.0 yang memiliki 6 derajat kebebasan (six degree of freedom) dengan sistem pergerakan yang ditunjukkan oleh Gambar 1. Posisi quadrotor pada sumbu-x, sumbu-y, dan sumbu-z ditulis sebagai,

$\mathrm{p}=\left[\begin{array}{lll}x & y & z\end{array}\right]^{\mathrm{T}}$.

Pergerakan roll, pitch, dan yaw yang dibentuk oleh sudur Euler dinotasikan dengan, $\alpha=\left[\begin{array}{lll}\varphi & \theta & \psi\end{array}\right]^{\mathrm{T}}$.

Persamaan (1) dan (2) diperoleh dengan mengintegrasikan data hasil pengukuran sensor accelerometer dan sensor gyroscope.

Hasil integrasi data pengukuran sensor accelerometer dan sensor gyroscope selalu berada dalam kerangka quadrotor, namun posisi dan arah quadrotor berada pada kerangka global. Agar hasil integrasi data pengukuran sensor accelerometer dan sensor gyroscope berada dalam kerangka global, diperlukan suatu transformasi koordinat untuk mengubah perpindahan linear dan perpindahan angular dalam kerangka quadrotor menjadi perpindahan linear dan angular pada kerangka global.

Tranformasi dari kerangka quadrotor menjadi kerangka global dilakukan dengan menggunakan matriks rotasi. Menurut [10] urutan rotasi matriks dimulai dari rotasi kerangka quadrotor terhadap sumbuz kerangka global, kemudian dilanjutkan dengan rotasi terhadap sumbu-y dan yang terakhir adalah rotasi terhadap sumbu-x. Matriks rotasi terhadap sumbu-x, sumbu-y, dan sumbu-y diberikan oleh persamaan (3), (4), dan (5),

$R_{x}(\varphi)=\left[\begin{array}{ccc}1 & 0 & 0 \\ 0 & \cos \varphi & -\sin \varphi \\ 0 & \sin \varphi & \cos \varphi\end{array}\right]$, 
$R_{y}(\theta)=\left[\begin{array}{ccc}\cos \theta & 0 & \sin \theta \\ 0 & 1 & 0 \\ -\sin \theta & 0 & \cos \theta\end{array}\right]$,

$R_{z}(\psi)=\left[\begin{array}{ccc}\cos \psi & -\sin \psi & 0 \\ \sin \psi & \cos \psi & 0 \\ 0 & 0 & 1\end{array}\right]$.

Berdasarkan urutan rotasi, matriks transformasi kerangka quadrotor menjadi kerangka global didapatkan melalui persamaan (6),

${ }^{W} R_{B}=R_{z}(\psi) \cdot R_{y}(\theta) \cdot R_{x}(\varphi)$

sehingga diperoleh persamaan (7) yang merepresentasikan matriks transformasi dari kerangka quadrotor menjadi kerangka global,

$$
{ }^{W} R_{B}=\left[\begin{array}{ccc}
c_{\theta} c_{\psi} & s_{\varphi} s_{\theta} c_{\psi}-c_{\theta} s_{\psi} & c_{\varphi} s_{\theta} c_{\psi}+s_{\varphi} s_{\psi} \\
c_{\theta} s_{\psi} & s_{\varphi} s_{\theta} s_{\psi}-c_{\varphi} c_{\psi} & c_{\varphi} s_{\theta} s_{\psi}-s_{\varphi} c_{\psi} \\
-s_{\theta} & s_{\theta} c_{\psi} & c_{\varphi} c_{\theta}
\end{array}\right]
$$

dengan, $c_{\varphi}=\cos \varphi, s_{\varphi}=\sin \varphi, c_{\theta}=\cos \theta, s_{\theta}=\sin \theta, c_{\psi}=\cos \psi$, dan $s \psi=\sin \psi$.

Hubungan antara sudut Euler $(\varphi, \theta, \psi)$ dengan posisi pada kerangka quadrotor diberikan oleh persamaan (8),

$$
\left[\begin{array}{l}
x_{w} \\
y_{w} \\
z_{w}
\end{array}\right]={ }^{W} R_{B} \cdot\left[\begin{array}{l}
x_{b} \\
y_{b} \\
z_{b}
\end{array}\right]
$$

dengan $x_{w}, y_{w}$ dan $z_{w}$ merupakan posisi pada kerangka global serta $x_{b}, y_{b}$ dan $z_{b}$ merupakan posisi pada kerangka quadrotor.

\section{PERANCANGAN SISTEM PENAPISAN}

\subsection{Gravity Compensator}

Percepatan linear yang dialami oleh quadrotor akan diukur oleh sensor accelerometer, akan tetapi sensor accelerometer tidak hanya mengukur percepatan linear quadrotor namun juga percepatan gravitasi. Keberadaan percepatan gravitasi yang terukur oleh sensor accelerometer ini akan mengganggu hasil pengukuran karena quadrotor seolah-olah mengalami percepatan sebesar percepatan gravitasi ke aarh sumbu-z. Kompensator gravitasi bertujuan untuk menghilangkan pengaruh percepatan gravitasi pada pembacaan sensor accelerometer. Persamaan kompensator gravitasi diperoleh berdasarkan transformasi koordinat, persamaan ini diberikan oleh persamaan (9),

$$
\left[\begin{array}{l}
0 \\
0 \\
g
\end{array}\right]={ }^{W} R_{B}\left[\begin{array}{c}
g_{b x} \\
g_{b y} \\
g_{b z}
\end{array}\right]
$$

sehingga persamaan kompensator gravitasi dapat dituliskan sebagai persamaan (10),

$$
\left[\begin{array}{l}
g_{b x} \\
g_{b y} \\
g_{b z}
\end{array}\right]=\left({ }^{W} T_{B}\right)^{-1} \cdot\left[\begin{array}{l}
0 \\
0 \\
g
\end{array}\right]
$$

dengan $g$ adalah percepatan gravitasi bumi $\left(9,812865328 \mathrm{~m} / \mathrm{s}^{2}\right)$, sedangkan $g_{b x}, g_{b y}$, dan $g_{b z}$ merupakan kompensator gravitasi untuk data sumbu $x, y$, dan $z$. 


\subsection{Kalman Filter}

Kalman filter merupakan algoritme yang banyak dipakai dalam hal penapisan noise serta untuk memperkirakan state dari sistem [11]. Proses rekursif ini pertama kali diperkenalkan oleh Rudofl. E Kalman dalam papernya di tahun 1960. Dalam Kalman filter sistem diasumsikan sebagai sistem yang linear dan semua variabel yang diamati direpresentasikan dalam distribusi Gaussian

Dalam teori kendali modern, state pada quadrotor yang diberikan oleh persamaan (7) dapat direpresentasikan sebagai persamaan linear yang diberikan oleh persamaan (11),

$\varsigma_{k+1}=A \varsigma_{k}+B u_{k}+w_{k}$

sedangkan hubungan antara state proses dan hasil pengukuran dinyatakan dalam persamaan (12),

$z_{k}=C x_{k}+v_{k}$

Dalam penelitian ini, algoritma penapisan yang dirancang dilengkapi dengan algoritme zero velocity compensator (ZVC). Zero velocity compensator adalah suatu metode yang digunakan untuk menghilangkan dampak yang ditimbulkan oleh noise pada sensor yang membuat pergeseran posisi dan arah sensor ketika sensor dalam keadaaan diam. Menurut [12], agar sensor dapat secara otomatis mengetahui dalam keadaan diam dapat dilakukan dengan membandingkan simpangan baku data dari sensor $\left(\sigma_{\mathrm{s}}\right)$ dengan nilai tertentu $\left(\sigma_{\mathrm{th}}\right)$. Jika deviasi standar data kurang dari nilai tersebut, maka sensor dianggap dalam keadaan diam, dan sebaliknya. Saat sensor berada dalam keadaan diam, maka kecepatan angular, perpindahan angular, percepatan linear, kecepatan linear, dan perpidahan linear sensor dianggap 0 .

Zero velocity compensator juga dapat digunakan untuk mengatasi perubahan offset pada sensor. Ada kalanya, nilai offset data sensor pada saat diam setelah digerakkan berbeda dengan nilai offset data sensor pada saat diam sebelum digerakkan (terjadi histerisis) sehingga, pada saat sensor diam selain hasil estimasi Kalman filter yang akan dibuat menjadi 0, nilai offset sensor juga diperbarui. Pengimplementasi zero velocity compensator pada Kalman filter diberikan oleh Gambar 2.

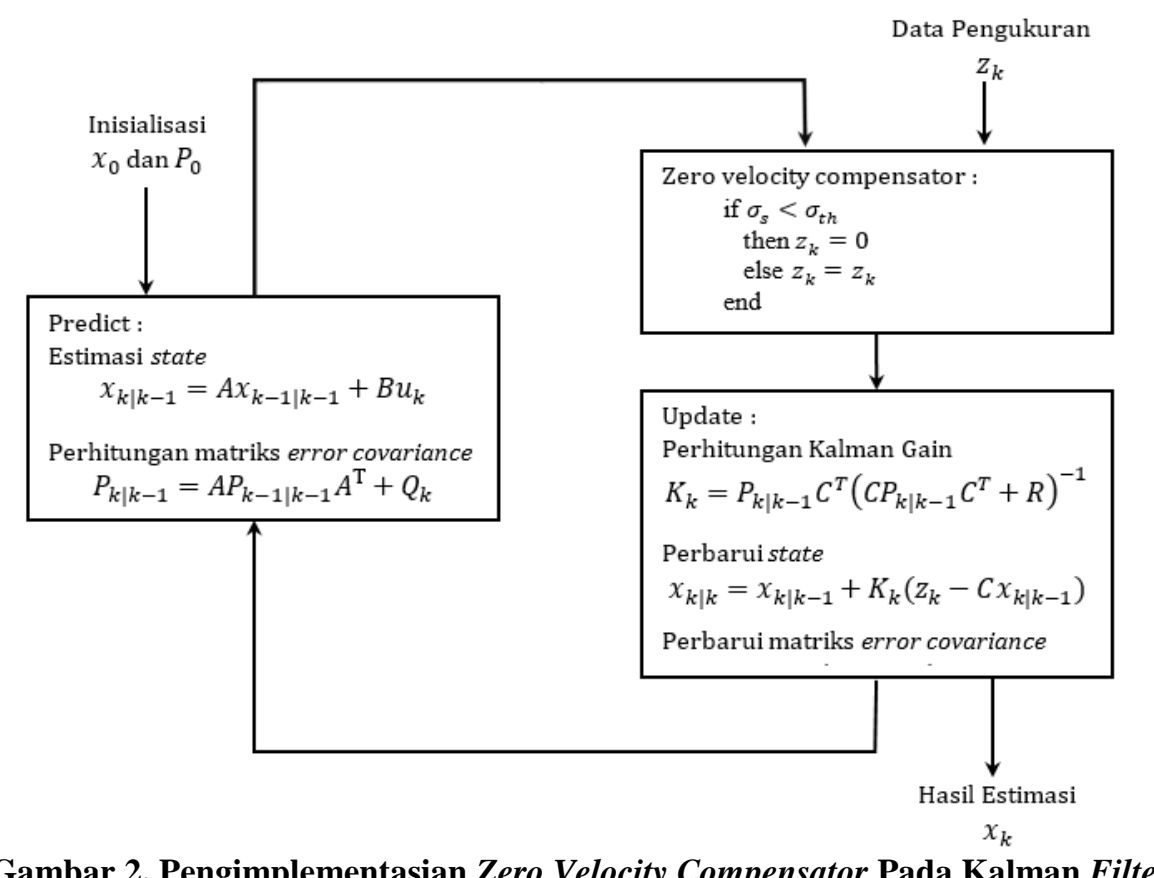

\section{HASIL DAN ANALISIS}

\subsection{Penapisan Pada Keadaan Statis}

Pengujian ini bertujuan untuk mengetahui apakah mengetahui apakah zero velocity compensator yang dirancang telah mampu menghilangkan drift yang terjadi ketika quadrotor dalam keadaan diam. Hasil penapisan derau ketika quadrotor dalam keadaan statis ditunjukkan oleh Gambar 3 dan Gambar 4. 


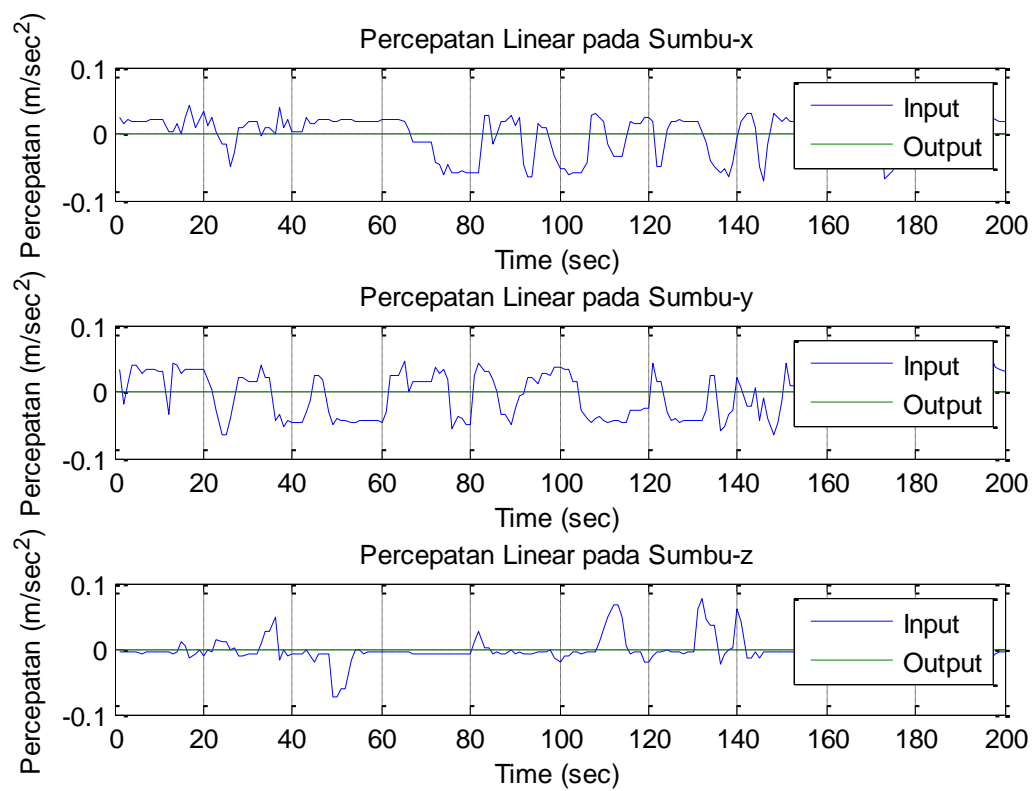

Gambar 3. Percepatan Quadrotor Saat Keadaan Statis

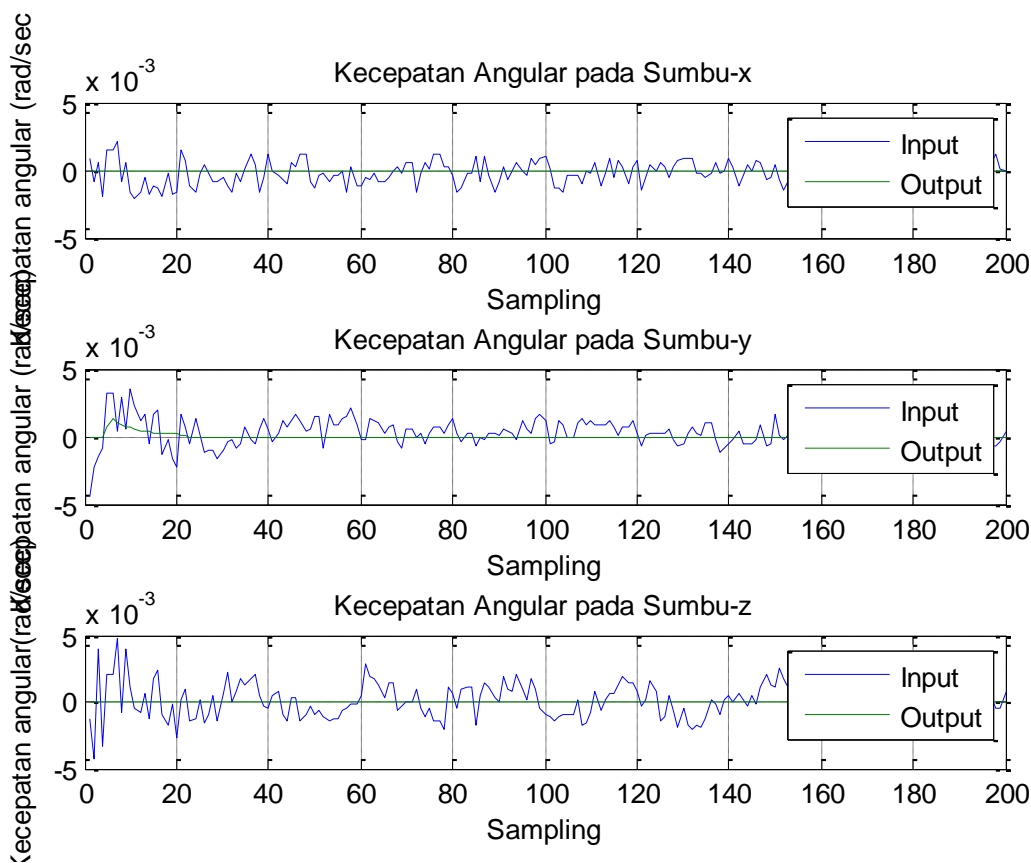

Gambar 4. Hasil Penapisan Kecepatan Angular Quadrotor

Berdasarkan Gambar 3 dan Gambar 4, terlihat bahwa zero velocity compensator yang dirancang telah berhasil membuat hasil pengukuran percepatan linear dan kecepatan angular sensor (garis warna biru) menjadi nol (garis warna hijau).

\subsection{Perpindahan Linear Dan Angular}

Untuk mengetahui apakah algoritme penapisan yang dirancang pada sensor accelerometer dapat berjalan dengan baik, quadrotor sejauh 2 meter terhadap sumbu-x, kemudian sejauh 2 meter terhadap sumbu-y, dan sejauh 1,5 meter terhadap sumbu-z. Gambar 5 merupakan hasil estimasi Kalman filter ketika quadrotor digerakkan secara linear terhadap masing-masing sumbu. 


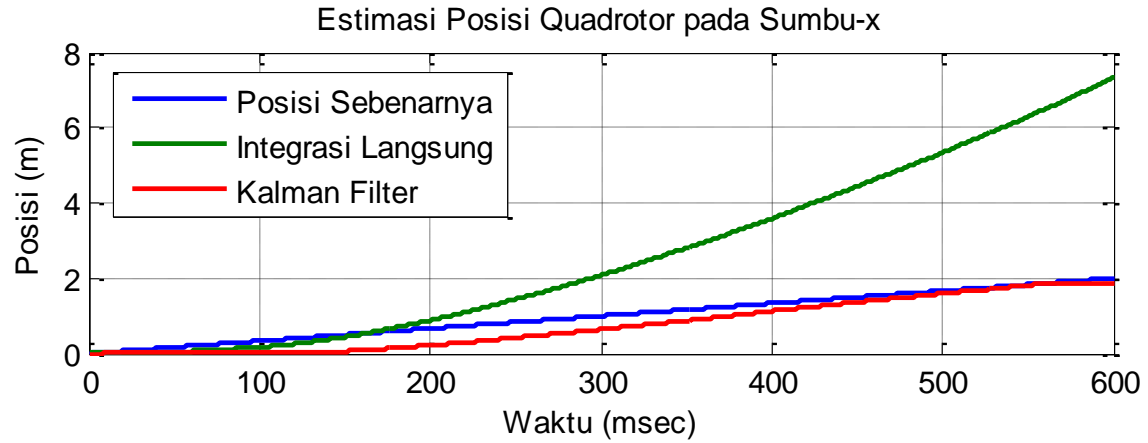

Estimasi Posisi Quadrotor pada Sumbu-y

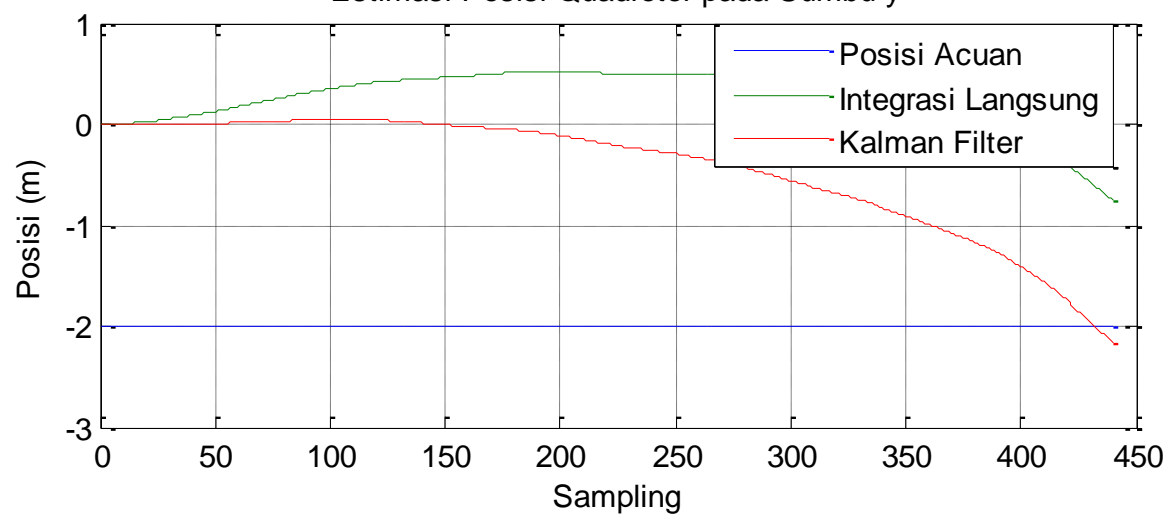

Estimasi Posisi Quadrotor pada Sumbu-z

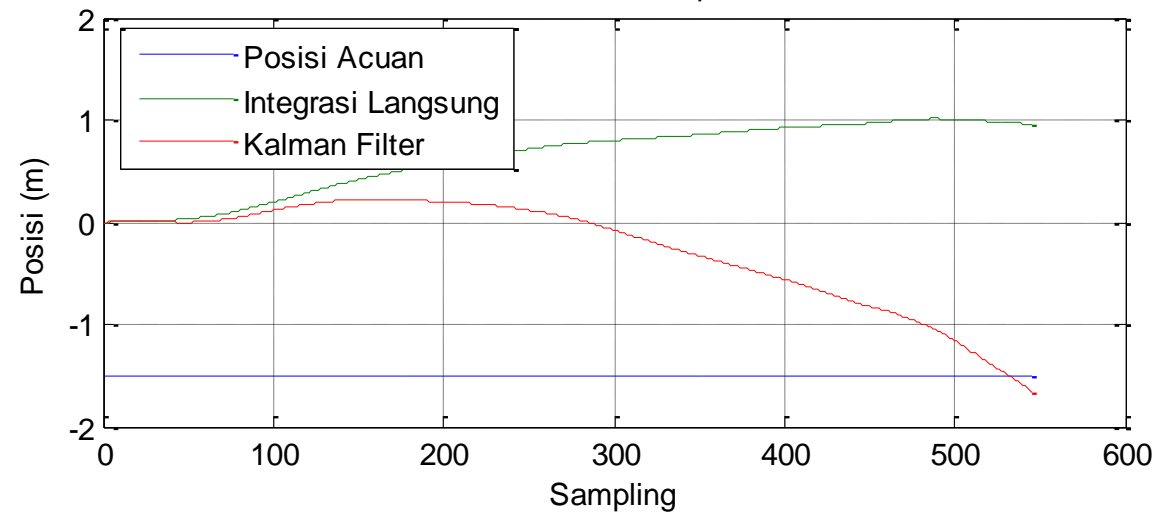

Gambar 5. Hasil Estimasi Posisi Quadrotor

Berdasarkan eksperimen yang dijalankan seperti yang terlihat pada Gambar 5, garis berwarna biru merupakan posisi acuan, posisi biru merupakan hasil integrasi secara langsung dan garis berwarna merah adalah hasil estimasi Kalman filter, ketika quadrotor digerakkan sejauh $2 \mathrm{~m}$ pada sumbu-x diperoleh hasil estimasi sebesar 7,329 m dengan menggunakan integrasi secara langsung dan 1,96 m dengan menggunakan Kalman filter, sedangkan pada sumbu-y, ketika quadrotor digerakkan sejauh $-2 \mathrm{~m}$ hasil estimasi dengan itegrasi langsung sebesar -0,3 m dan -2,17 m dengan menggunakan Kalman filter. Ketika quadrotor digerakkan sejauh $-1,5 \mathrm{~m}$ pada sumbu-z diperoleh hasil sebesar 1,01m dengan menggunakan itegrasi langsung dan hasil yang diperoleh dengan menggunakan Kalman filter adalah sebesar -1,7 m. Dengan melihat hasil-hasil tersebut terlihat bahwa Kalman filter yang dirancang telah berhasil mengurangi derau yang tercampur pada data pengukuran sensor accelerometer.

Selanjutnya untuk mengetahui apakah algoritme penapisan ini berhasil mengurangi derau pada sensor gyroscope, kerangka quadrotor diputar sebesar $90^{\square}$ terhadap sumbu-x, sumbu-y, dan sumbu-y. Berikut merupakan hasil estimasi Kalman filter ketika dilakukan pergerakan angular terhadap kerangka quadrotor. 


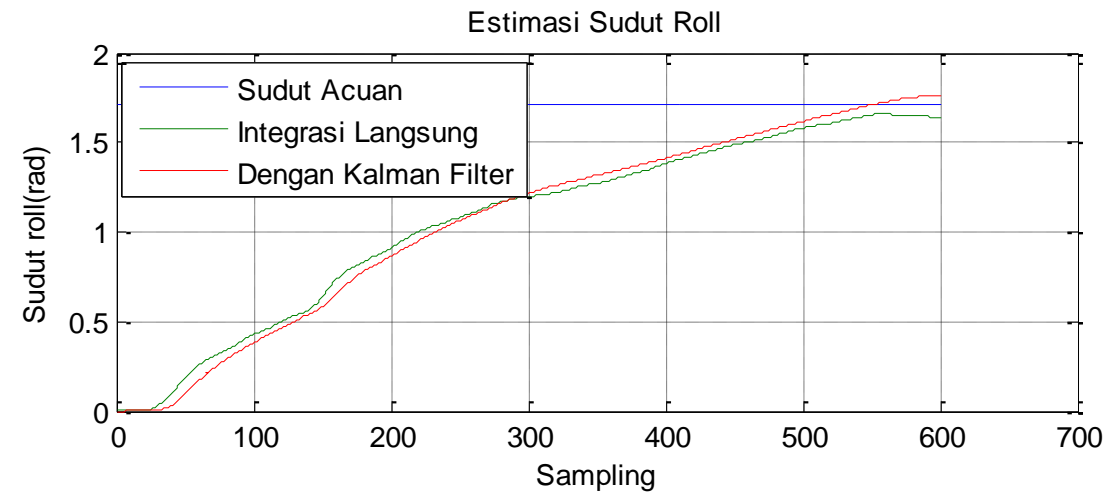

Estimasi Sudut Pitch
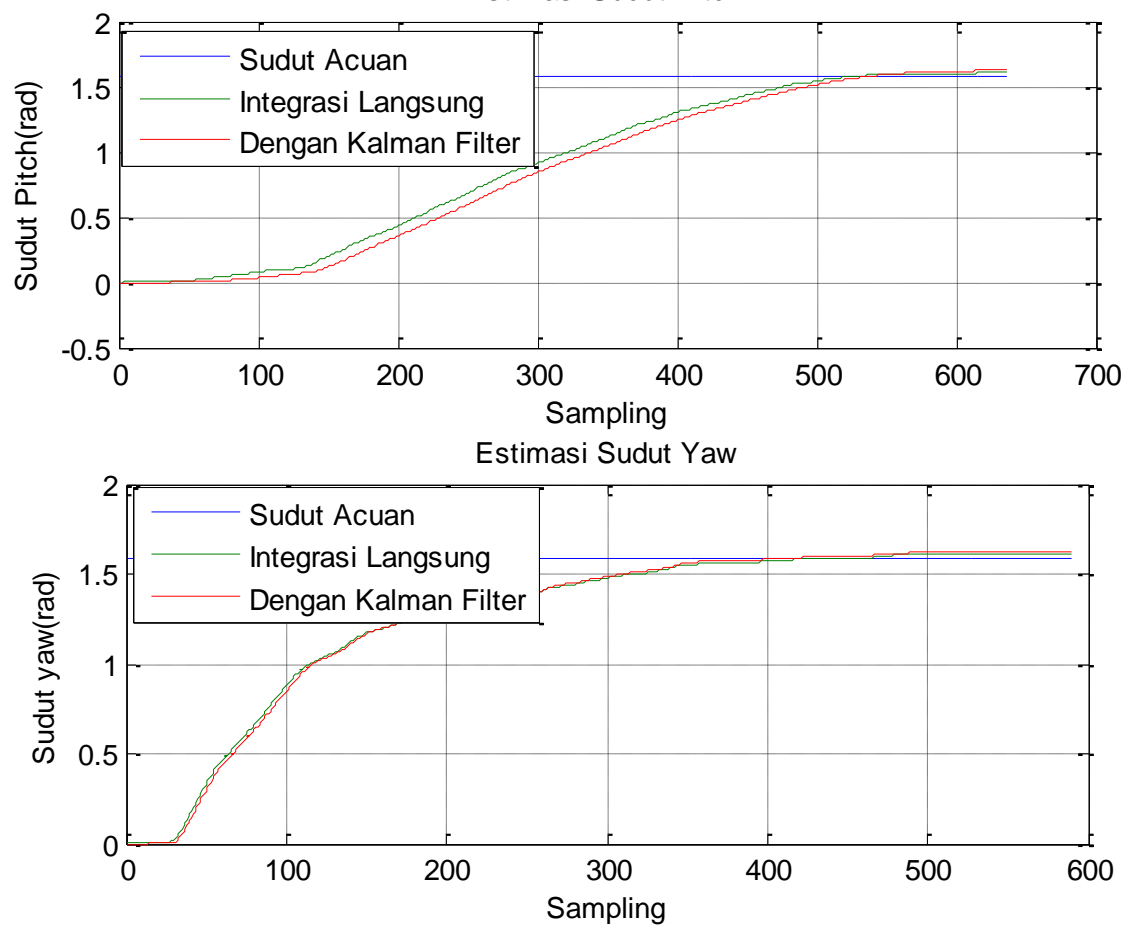

Gambar 6. Hasil Estimasi Sudut Quadrotor

Hasil akhir estimasi sudut yang diperoleh seperti yang ditunjukkan oleh Gambar 6, dengan garis berwarna biru merupakan sudut acuan, garis berwarna hijau merupakan hasil integrasi secara langsung dan garis berwarna merah menunjukkan hasil estimasi dengan Kalman filter, adalah sebesar $87^{\square}$ dengan integrasi langsung dan 92,8 dengan estimasi menggunakan Kalman filter pada sudut roll, sedangkan pada sudut pitch diperoleh estimasi sudut sebesar $92^{\square}$ dengan itegrasi langsung dan 92,8 ${ }^{\square}$. Pada sudut yaw diperoleh sudut sebesar $92,6^{\square}$ dengan estimasi tanpa penapisan dan $93^{\square}$ dengan menggunakan Kalman filter.

\section{KESIMPULAN}

Dalam penelitian ini dirancang algoritme penapisan yang bertujuan untuk mengurangi derau yang ada pada hasil pengukuran sensor inersia quadrotor. Berdasarkan pengujian yang telah dilakukan algoritma zero velocity compensator yang dirancang telah mampu mengurangi pergeseran (drift) pada saat quadrotor dalam keadaaan diam, selain itu Kalman filter yang digunakan pada sensor accelerometer dan sensor gyroscope telah dapat mengurangi derau yang tercampur pada raw data, sehingga hasil integrasi perpindahan lebih baik dibandingkan dengan hasil integrasi tanpa penapisan.

\section{DAFTAR PUSTAKA}

[1] D. H. Shim, H. J. Kim, and S. Sastry. 2000. "Control System Design for Rotorcraft-based Unmanned Aerial Vehicles using Time-domain System Identification,” Proc. 2000 IEEE Int. Conf. Control Appl., no. 2, pp. 808-813. 
[2] M. Achtelik, A. Bachrach, R. He, S. Prentice, and N. Roy. 2009. "Autonomous Navigation and Exploration of a Quadrotor Helicopter in GPS-denied Indoor Environments," Int. Aer. Robot. Compet.

[3] A. Bachrach, S. Prentice, and N. Roy. 2009. "RANGE - Robust Autonomous Navigation in GPSdenied Environments," J. F. Robot.

[4] C. Christmann, A. Wu, H. Hashimoto, C. Ong, R. Kalghatgi, and E. N. Johnson, "Self-Contained Ranging Sensor Aided Autonomous Guidance, Navigation, and Control for Indoor Flight," Am. Inst. Aeronaut. Astronaut., pp. 1-21.

[5] A. Bry, A. Bachrach, and N. Roy, "State estimation for aggressive flight in GPS-denied environments using onboard sensing,” 2012 IEEE Int. Conf. Robot. Autom., no. Icra 2012, pp. 1-8, May 2012.

[6] D. Li, Q. Li, N. Cheng, Q. Wu, J. Song, and L. Tang. 2013. "Combined RGBD-inertial based state estimation for MAV in GPS-denied indoor environments," 2013 9th Asian Control Conf., pp. 1-8, Jun.

[7] M. Achtelik, A. Bachrach, R. He, S. Prentice, and N. Roy. 2009. "Stereo vision and laser odometry for autonomous helicopters in GPS-denied indoor environments," Int. Soc. Opt. Eng., pp. 733219733219-10, May.

[8] L. R. García Carrillo, A. E. Dzul López, R. Lozano, and C. Pégard. 2011. “Combining Stereo Vision and Inertial Navigation System for a Quad-Rotor UAV,” J. Intell. Robot. Syst., vol. 65, no. 1-4, pp. 373-387, Aug.

[9] R. Voigt, J. Nikolic, C. Hurzeler, S. Weiss, L. Kneip, and R. Siegwart, "Robust embedded egomotion estimation,” 2011 IEEE/RSJ Int. Conf. Intell. Robot. Syst., pp. 2694-2699, Sep. 2011.

[10] R. M. Murray, Z. Li, and S. S. Sastry. 1994.A Mathematical Introduction to Robotic Manipulation. Berkeley: University of California,

[11] J. J. Engel. 2011. “Autonomous Camera-Based Navigation of a Quadrotor,” DER TECHNISCHEN UNIVERSITA" T MU" NCHEN.

[12] C. Chiu. 2008. "Error Reduction Techniques for a MEMS Accelerometer-based Digital Input Device," The Chinese University of Hong Kong. 